ARTICLE

DOI: $10.1057 / \mathrm{s} 41599-018-0173-\mathrm{x}$

\title{
How Burkina Faso used evidence in deciding to launch its policy of free healthcare for children under five and women in 2016
}

\author{
Valéry Ridde (i) ${ }^{1} \&$ Pierre Yaméogo ${ }^{2}$
}

\begin{abstract}
In March 2016, the newly elected government of Burkina Faso decided on a major change in health financing policy: it abolished direct payment for healthcare for women and children under five. Unlike other countries in Africa, this decision took a long time, given that the first pilot projects for this policy instrument date from 2008. This article describes that political process and presents a reflexive analysis by two authors who were at the heart of events between 2008 and 2018. The analysis shows that, while the decision took a long time and certainly amounted to a policy paradigm shift, it was the result of a complex series of events and activities whose specific contributions are difficult to identify. Crucial to the decision was long-term funding of pilot projects to test the new policy instrument, associated with the generation of evidence mobilised through a myriad of knowledge transfer activities. Moreover, it took the continued mobilisation of advocacy coalitions, action to counter preconceived notions about this instrument, and the emergence of an essential window of opportunity-the 2014 popular uprising-for the decision to be possible. In this discussion, we generalise to the conceptual and theoretical levels, but also share practical lessons learned for those interested in engaging in evidence-informed decision-making. The main lessons are: recruit, train, and mobilise people and/or services responsible for knowledge transfer activities; identify and partner with political entrepreneurs early and regularly; be persistent and consistent in producing rigorous and useful knowledge; favour independent evaluation teams using mixed methods; train researchers in policy decision-making processes and decision-makers in knowledge production issues; adapt (content, format, vocabulary, language, etc.) the evidence to the needs of the knowledge users in close collaboration with researchers and disseminate it to target audiences; understand the sometimes different logics of researchers and decision-makers and encourage their interaction; to seize opportunities, regularly analyse the political decision-making processes specific to the national context as well as the social and political contexts favourable (or not) to decision-making.
\end{abstract}

\footnotetext{
${ }^{1}$ IRD (French Institute For Research on sustainable Development), CEPED (IRD-Université Paris Descartes), Universités Paris Sorbonne Cités, ERL INSERM SAGESUD, Paris, France. ${ }^{2}$ Ministry of Health, Universal Health Coverage Office, Ouagadougou, Burkina Faso. Correspondence and requests for materials should be addressed to V.R. (email: valery.ridde@ird.fr) or to P.Y. (email: yampite@gmail.com)
} 


\section{Introduction}

$t$ the end of 2017, in an interview with TV5 Monde, the highly watched international French-language channel in Africa, the new President of the Republic of Burkina Faso highlighted the free healthcare policy decreed by the government on March 2, 2016, as one of his key political actions to alleviate poverty. While the journalist's question was surprising, reproaching the President that poverty had not diminished after two years of his mandate, the answer is particularly interesting to study. This political decision in Africa, highlighted by a President, warrants reflexive analysis. Indeed, the institutionalisation of direct payment (user fees) for healthcare in the early 1990s in Africa and the first pilot projects for user fees exemption in the late 2000s in Burkina Faso (Ridde, 2015) were part of a long and complex process leading ultimately to the adoption of the free care policy in 2016.

In Africa, " 80 percent of countries ( 37 of the 41 countries that had use fees) have implemented reforms to reduce or eliminate user fees" (Cotlear and Rosemberg, 2018). However, several studies have shown that the decisions to introduce these user fees exemption policies in Africa were often electorally motivated, sudden, prompted by external pressures, and consequently very chaotic in their implementation (Meessen et al., 2011; Ridde, Queuille, et al., 2012; Olivier de Sardan and Ridde, 2015; Gautier and Ridde, 2017), even if their effects were often beneficial for populations. This was still the case at the end of 2017, such as in Gabon, where the President suddenly announced exemption from payment for deliveries without anything having been prepared on the ground. These policies are obviously essential, because asking patients to pay at the point of care is known to be one of the biggest barriers to access to care (Robert et al., 2017). Yet contrary to international recommendations and discourse (Robert and Ridde, 2013), many countries in Africa continue to impose user fees for certain services or categories of people, thereby hindering the achievement of universal health coverage (UHC) and Sustainable Development Goal 3. For example, in some African countries, the practice persists of detaining patients in hospitals because they cannot pay for their care (Yates, Brookes and Whitaker, 2017), and there has been a return to some forms of user fees for HIV patients, which was denounced at the UHC Forum in Tokyo in December 2017 (MSF, 2017). Thus, the right to access healthcare is still far from being respected in many countries, and there is a persistent gap between decisions and their actual implementation. The role of preconceived ideas with respect to this policy instrument is also certainly not negligible (Ridde, Queuille and Ndour, 2014).

Unlike some countries that rushed into such decisions, with the result that their policies were not as effective as intended (Meessen et al., 2011; Olivier de Sardan and Ridde, 2015), Burkina Faso offers a rather exceptional history that merits the present analysis. The process took almost 10 years, from the time of first discussions and pilot projects to the moment of deciding to eliminate user fees for children under five and pregnant women. The objective of this article is to describe and analyse this story using a reflexive approach.

\section{Methods}

In this commentary article, we analyse this process based on our participation as a long-standing researcher (VR) and a technical advisor and decision-maker (PY) involved in this policy process. Our approach is reflexive, defined for the purposes of this article as "an intended and conscious intellectual activity in which individuals (or groups) explore or examine their experiences to develop new understandings that ultimately shape their actions" (Tremblay and Parent, 2014).
Reflexivity is essential for professional development, especially for public health researchers (Tremblay and Parent, 2014). In this article, we adopt a posteriori a reflexive posture on action, which in this case is the process that led to the decision to abolish user fees.

The following paragraphs briefly present the careers of the two authors of this article, as well as our place and involvement in the policy studied, so that the reader may better understand our stance with respect to this analysis. While not social scientists per se, we follow the development of knowledge on public policies and the science of using science and draw upon their concepts and theories in this reflexive analysis. While we support user fees exemption policies based on the state of the art on their effectiveness, we have also published on or participated in projects that have shown their ineffectiveness and implementation challenges or errors. Thus, we believe the analysis presented in this article is relatively distanced in this respect and neutral in terms of our reflexivity on the role of evidence.

VR is a public health researcher based in Canada (2007-2017), Burkina Faso (2010-2012,) and France (since 2018). Prior to his academic career, he was in charge of projects for public health NGOs in Africa. In 2007, he evaluated the healthcare user fees exemption project organised in Niger by a German NGO (HELP), which deployed a pilot intervention starting in 2008 in two districts of Burkina Faso (D'Ostie-Racine, Dagenais and Ridde, 2016). VR coordinated a substantial research programme $(€ 1.2$ million) to analyse this HELP intervention, as well as numerous other studies on the national subsidy policy for childbirth adopted in 2006 by the government (Ridde et al., 2011; Nguyen et al., 2018). This involved a large number of international and national researchers, research assistants, and students.

PY was the chief medical officer of Tougan health district from 2007 to 2011, where another NGO (Tdh) tested an intervention for healthcare user fees exemption (Blanchet, Zonon and Aggagliate, 2012). He was involved in the design and implementation of the exemption in this district from 2011 to 2015. Subsequently, he carried out the feasibility study, designed the national strategy, and drafted the advocacy document on this national policy. At the same time, he supported NGOs as a consultant in advocating for this instrument. Since 2016, he has been the national coordinator for implementation of the national exemption policy. In October 2017, he was appointed the Technical Secretary in charge of Universal Health Coverage at the Ministry of Health, coordinating the national healthcare user fees exemption policy.

The data for this analysis come from our notes and reflections compiled over the course of our involvement in this policy since 2008 , as well as from observation (sometimes participant) of all the events we present below. We used all available literature, whether scientific or grey, to support our analysis. Writing this article was also a process of support for our reflection. First, we agreed on the content of the article within the three dimensions of the chosen conceptual framework (see below). Then for the writing, under VR's leadership, we shared the content and compared our perspectives throughout the drafting of the different versions of the article, including its revision after reviewers' comments. Writing the discussion allowed us to associate reflection with concepts more widely used in political science. We presented the preliminary results of our reflections at two international conferences in Senegal and Japan in 2017.

The description and analysis we present here fall within the scope of the study of public policies and, more specifically, of the role of evidence in defining robust public policies, shaping ideas, and supporting advocacy coalitions in moving the issue onto the political the agenda (Ridde, 2009; Pawson, 2013; Sabatier and 
Weible, 2014; Béland, 2016). It is often recommended that policy change analysis should cover a long time frame of at least 10 years (Sabatier and Weible, 2014), and we have done this in our analysis.

In this article we use the approach proposed by Hassenteufel (2010) because it is more conducive to our descriptive and reflexive approach. Other agenda-setting frameworks call for an empirical-analytical approach that goes beyond the intent of our article and will need to be mobilised later. According to Hassenteufel's (2010) model, the process leading to this public policy decision consisted of three phases: mobilisation (drawing attention to the problem and its solutions), mediatisation (making them public, in particular with media), and politicisation (obtaining political benefits). Obviously, this triple dynamic occurred within a specific context, which we will first present.

\section{Findings}

Context. Burkina Faso is a country with limited resources for health financing, with only $\$ 46.8$ per capita health expenditure in 2016 (Ministère de la santé, 2017). The health system is thus hampered by inadequate resources and is strongly dependent on healthcare user fees, which have remained the primary source of health financing. Health policy is focused on primary health care, which is the basis of the health system.

Despite efforts made over the past 10 years, the level of healthcare coverage among the population remains very low, at around $39 \%$ according to the 2017 health services coverage index (WHO and World Bank, 2017). Human, material, and technical medical resources are insufficient in both quantity and quality and often poorly distributed. The North, North Central, and Sahel regions concentrate scarce human resources to meet basic reproductive health needs precisely where the first pilot user fees exemption projects began in 2008. Burkina Faso does not have functional health insurance, so healthcare user fees are the mechanism promoted by health policy to help finance the health sector. However, numerous studies have shown this leads to very low use of care (Ridde et al., 2014). While some forms of user fees exemption had long existed for certain diseases (tuberculosis, HIV, malnutrition), an initial ambitious subsidy policy was launched in 2006 for deliveries and newborns under seven days of age; this was not, however, an exemption (i.e., full subsidy). Financed entirely by the State, it has been relatively well implemented and has proved very effective, including for the poorest (Ridde et al., 2011, 2015; Nguyen et al., 2018). Nevertheless, financial barriers remain high for women and children.

In early 2012, a report hypothesised that, despite the abundant data produced on health financing in Burkina Faso, little knowledge seemed to have been mobilised by decision-makers (Ridde, Zerbo, et al., 2012). The two worlds did not seem to have influenced each other much. However, the story has since changed, as we will see in this article.

\section{Mobilisation}

Pilot experiences and NGO coalition. It is in this context that the European Union and its Humanitarian Aid Office (ECHO) embarked in 2008 on a wide-ranging plan to reduce malnutrition. Their aim was to support NGOs wishing to organise pilot projects to implement user fees exemption for health services, one of the major determinants in the fight against malnutrition. (DG ECHO, 2007). Pilot experiments on free healthcare financed by ECHO under this Sahel plan were conducted by several international NGOs (HELP, Terre des hommes (Tdh), Action Contre la Faim (ACF), Save the Children International (SCI), Médecins du Monde $(\mathrm{MdM})$ ) in a limited number of health districts (Tougan, Séguénéga, Dori, Sebba, Diapaga, Fada, Kaya). They have been of varying magnitude and duration, but some have been sustained for more than eight years.

Much evidence has been generated about these pilot interventions.

On one hand, while scientific evidence has shown the challenges of implementing the exemption, it has also revealed its capacity to reduce catastrophic health expenditure, improve the use of health centres, and redress inequities (Ridde et al., 2014). A simulation published in 2014 showed that if the exemption strategy tested in the pilot projects were implemented on a national scale, it would save between 14,000 and 19,000 children under five per year-a $16 \%$ reduction in the child mortality rate (Johri et al., 2014). Qualitative studies have also shown that user fees exemption can strengthen women's empowerment (Samb and Ridde, 2018).

On the other hand, these NGOs also produced tacit knowledge that they built on as their projects progressed and shared with Ministry of Health technicians and decision-makers at the central, regional, and local levels. This knowledge was related to topics such as: processes for monitoring and verifying the exemption; flat-rate reimbursement methods; contents of the services package; computerised medical records; monitoring tools; approaches for targeting the indigent; etc. As a result, several good practice guides have been written by these NGOs in collaboration with health system actors.

Based on their experience of successful interventions, these NGOs launched various advocacy efforts with the support of Amnesty International and donors (ECHO, UNICEF, WHO) with a view to scaling up free healthcare.

The NGOs organised numerous meetings to discuss and present results at the level of the Ministry of Health. For example, in 2009, the results were presented at the annual meeting of all district medical officers and regional health directors from across the country. Some NGOs had provided upstream support to the presenters, who were the chief medical officers of the districts where the pilot projects were being implemented.

In July 2010, a joint mission (PY, VR, NGOs, and other researchers) took part in the 20th World Conference of the International Union of Health Promotion and Education. The first results of the pilot experiments were brought to the attention of the participants (especially researchers and international NGOs) through presentations and posters.

Feasibility study of the national strategy in 2012. At the end of 2011, donors organised a special advocacy meeting for technical and financial partners (TFP) on scaling up the user fees exemption for children under five and pregnant women. The Ministry of Health received this plea favourably and embarked on a process of studying the feasibility of free healthcare at the national level. This main objective of this study, conducted in 2012, was to estimate the costs of eliminating user fees at the national scale and to identify the conditions for success. An international consultant from the London School of Hygiene and Tropical Medicine, paid by Tdh, was made available to the Ministry of Health team to conduct this study.

The report from that study was submitted to decision-makers in the Ministry of Health (the central directors) in December 2012. The study stated in particular that "A scaling up of free care for children under 5 costs between 9.89 billion FCFA and 12.18 billion FCFA per year. However, it should be noted that these figures are only plausible if rigorous and effective control accompanies the introduction of free access in health centres" (Ministère de la Santé, 2012). The main recommendation that emerged from this feasibility study feedback meeting was that a national strategy document be drafted for the implementation of free care for children under five and pregnant women. 
Development of the national strategy. With technical and financial support from UNICEF, ECHO, WHO, and NGOs, the Ministry of Health continued its reflection through the preparation of a strategy document for implementing free healthcare at the national level. A team of key actors (service providers, NGOs, central level of the Ministry of Health, international donors) met in a workshop in the city of Koudougou from March 12 to 15, 2013. The strategy (content) and an advocacy document (to influence decision-makers to adopt the content) were developed during this workshop. The two documents were presented at the Ministry of Health cabinet meeting in August 2013 and then officially transmitted to the TFPs by WHO (letter of October 7, 2013) for their opinion. Three of the 13 references cited in the strategy paper came from research on HELP's pilot intervention in the Sahel region, reflecting the use of the scientific evidence produced.

In December 2013, by correspondence, the TFPs were in favour of implementing the user fees exemption. They stressed the wish that this be done at the national level from the outset, building on the experience gained by NGOs and placing the financing of this strategy within the overall framework of a national health financing strategy for UHC.

Following this opinion, the Agence Française de Développement (AFD) approached the Ministry of Health several times between 2013 and 2015 to offer financial support to start the strategy. Indeed, AFD had just decided to deploy an intervention of $€ 30$ million, financed by the tax on financial transactions, to support the Sahel countries engaged in healthcare user fees exemption policies-the Initiative Santé Solidarité Sahel (I3S). Burkina Faso was eligible. In December 2013, a $€ 5$ million project for Burkina Faso was presented to the I3S identification committee in Paris. However, in May 2014, the Ministry of Health informed AFD that it wished to await the results of internal discussions and evaluations of its national strategy of subsidising deliveries before launching a feasibility study on I3S financing. AFD responded five months later, taking note of this position but announcing that it would not finance this feasibility study. It appeared AFD officials based in Burkina Faso, unlike those at the Paris headquarters, were not in favour of investing in the health sector (HERA, 2018). Thus, the financial support earmarked for Burkina Faso was redirected towards other Sahelian countries.

Then there was a slowdown. As ECHO funding for the pilot project was due to end in 2014, the Ministry of Health requested an extension, and ECHO granted an additional year of funding to the NGOs. At the beginning of 2015 the Ministry of Health also asked AFD to take over, after this additional year granted by ECHO, under its I3S initiative. However, in the end, no I3S funding was granted (HERA, 2018).

\section{Mediatisation}

Knowledge brokering. For four years an NGO (HELP) financed the presence of a knowledge broker to support researchers in making their work relevant and especially in implementing knowledge transfer strategies (Dagenais et al., 2013). Between 2008 and 2013 (but activities continued, see below), this NGO, with the help of researchers (VR's team) and the broker, mobilised $€ 1$ million to carry out this research (for a total of $€ 9$ million in pilot projects funding the user fees exemption), produced 16 peer reviewed articles, four $\mathrm{PhD}$ theses, two books, 25 policy briefs, five films and 38 scientific conference presentations. Research on this process has shown that the actors involved (NGOs, Ministry, researchers, etc.) confirmed the importance of its impact on advocacy (Queuille et al., 2013).
NGO coalition. The four main NGOs (Tdh, HELP, ACF, SCI) involved in implementing the pilot projects from the outset agreed in 2008 to create an informal coalition to strengthen their advocacy. This obviously was not easy, as NGOs often have their own agendas and sometimes seek to put themselves ahead of others. There was occasional tension, but the importance of the subject, the NGOs' belief that political decisions could be influenced by their work, and the donor's (ECHO) support of this process all contributed to the coalition's effectiveness. Then other NGOs joined the group, including Amnesty International (AI) and MdM. To our knowledge, this was the first time AI researchers committed themselves in the health field, which is not their usual area of expertise. They collaborated extensively with the NGO coalition on the ground, as well as with researchers to use evidence to support their report (Amnesty International, 2009). This report gave rise not only to many international advocacy activities, but also was especially helpful to the local AI office and other NGOs.

Media and press conferences. The various NGOs also engaged extensively with international, national, and regional media. The strategy deployed was wide-ranging so as not to rely on a single medium, because decision-makers in the capital are more likely to read paper newspapers, while the general public is more influenced by TV in the city and radio in rural areas. Thus, from 2010, multiple press conferences, workshops for journalists, and international (RFI) and national/regional radio broadcasts were organised. On at least three occasions, actors involved in user fees exemption (including PY, VR, and the broker) took part in the RFI health programme, which is widely listened to in Burkina Faso, Africa, and France. In April 2014, MdM produced a report on free healthcare and paid for its broadcast on national television, but after $48 \mathrm{~h}$, Ministry of Health officials asked MdM to stop broadcasting so as not to hinder internal discussions; it appeared this report was exacerbating contentious debates. At the same time, the Ministry also asked HELP to stop disseminating its documentation.

Politicisation. The politicisation phase was largely led by this coalition of NGOs at both the European and national levels.

At the European level. The European Commission's Humanitarian Aid Office (ECHO) played an important role not only in funding interventions and advocacy, but also in advancing the politicisation process. This was not easy, because it was also necessary to convince their colleagues in the development aid offices (different from those in the humanitarian aid office), who were quite resistant towards this policy instrument (Howlett, 2011), i.e., the healthcare user fees exemption.

At the end of 2012, ECHO successfully organised a visit by the European Commissioner for International Cooperation and Humanitarian Aid, a member of the European Commission, to the HELP intervention area. In a letter sent at the beginning of 2013, she congratulated the NGOs on this work of subsidising healthcare user fees, which had made it possible to advance beyond the declaration of principle issued by the ECHO Directorate-General in 2008 (ECHO, 2008) in this respect and to open the whole Commission to this instrument.

In February 2013, that same Commissioner discussed the "exceptional results" of this pilot experiment at a World Food Program summit in Rome on the Sahel. In her statement, she even quoted the study, not yet published (Johri et al., 2014), which showed a reduction in infant mortality associated with national implementation of healthcare user fees exemptions. The use by a senior decision-maker of research results not yet 


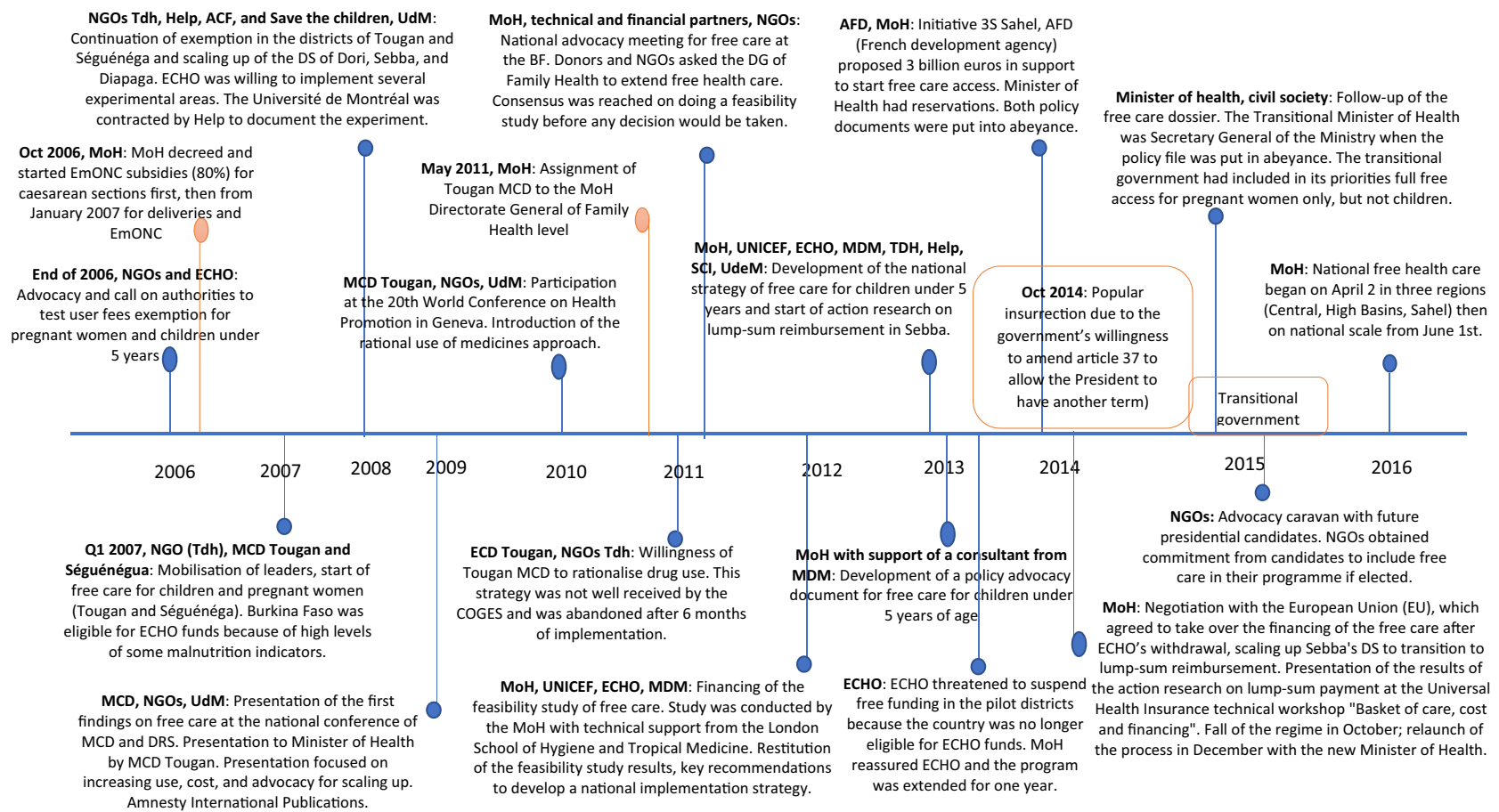

Fig. 1 Chronology of significant events and key stakeholders. NGO Non-governmental organization; EmONC Emergency Obstetric and Newborn Care; MoH Ministry of Health; Tdh or TDH Terre des hommes (NGO); ACF Action contre la faim (NGO); UdM or UdeM Université de Montréal; MCD médecin chef de district; DRS directeur regional de la santé; MdM médecin du monde; AFD Agence française de développement

published in a scientific journal also demonstrates the relevance of producing policy briefs before scientific publications so that the results can be quickly put to use by decision-makers (Dagenais and Ridde, 2018). A recent evaluation of SCI's 2015 advocacy campaign also showed the effectiveness of policy briefs in influencing decision-making (Baptist and Miletzki, 2017). In addition, the NGO coalition, accompanied by PY and the knowledge broker, went to Brussels in September 2012 to meet with decision-makers to advocate for ECHO funding, because the funding for the user fees exemption remained under debate and its sustainability was not ensured.

At the national level: from the presidency to the revolution. A great many advocacy activities based on evidence (sometimes using policy briefs) were carried out to politicise the issue at the national level. AI's investment culminated in a visit by its delegates and researchers to the President of the Republic in 2010. The President's commitment to free care was announced by AI to the media and on the Internet (Amnesty International, 2010). AI also organised a caravan in 2010 to travel to rural areas and to draw the attention of regional authorities and decision-makers to this policy instrument. In 2010, HELP produced a capitalisation report on its experience after two years (Ridde and Queuille, 2010), which it handed over to the First Lady in 2011, as it was not possible to meet with the President directly. Tdh also submitted its activity report on free care that year. The President responded with a letter of congratulations and encouragement for their commitment to the poorest. The NGO was decorated that year with the rank of Knight of the National Order.

In 2013, NGOs supported women's groups in the Sahel region to call on the President of the Republic during his visit to the region. That same year, a Harmonisation for Health in Africa community of practice organised a major conference on user fees exemption policies in Africa ${ }^{1}$, where more than 300 researchers, experts, and stakeholders debated these issues. It was also an opportunity for France's Deputy Minister for Development, in the presence of the Minister of Health of Burkina Faso, to announce the launch by France of I3S, which in the end, however, did not support the country in its efforts. During this conference, Canadian researchers ${ }^{2}$ provided training in knowledge transfer practices and policy brief writing.

Despite all this advocacy undertaken with scientific evidence, there remained a certain amount of caution/resistance, and the process slowed during 2014. Then a major event changed the course of history. On October 30, 2014, when the National Assembly was due to debate the universal health insurance (AMU) policy, the President, a man who had been in power for 27 years, decided to change the agenda and asked parliamentarians to vote on an amendment to the Constitution that would allow him to stand again in the next presidential election. In the end, neither the AMU nor the amendment was discussed. The National Assembly was burned down in a citizens' revolt that drove out the President. A transitional government was put in place. It was this government that voted in September 2015 to adopt a law on the AMU, in which the user fees exemption for indigents was included in article 18 . While the exemption did not yet apply to women and children, that decision, with the acceptance of this policy instrument, marked the beginning of a paradigm shift.

However, the national user fees exemption strategy for children and women still had not been adopted. In 2015, SCI was able to obtain funding of $€ 110,000$ to carry out numerous advocacy activities in the context of the NGO coalition. These took the form of an extensive media campaign "Ma Voix, la santé des enfants" (My voice, children's health), that included organising visits by journalists to the field. The organisation also produced policy briefs and mobilised the national permanent secretariat of NGOs (SPONG) (Baptist and Miletzki, 2017). Thus, the NGO coalition got back on track and developed numerous advocacy activities aimed at candidates for the new (and unprecedented) presidential campaign. All candidates were met and urged to take a public stand. The coalition of NGOs set up a committee to 
monitor presidential commitments in this area. A recent evaluation showed that "the campaign's messaging was timed for maximum impact [...] The timing was opportune in the sense that after the popular uprising in 2015, there was appetite for political change and the voice of the people held increased weight and importance in the national political discourse" (Baptist and Miletzki, 2017).

The free healthcare policy was finally decreed on March 2, 2016, at the Council of Ministers of the new government, just four months after the first free elections, but eight years after the first pilot projects organised by NGOs. The then Minister of Health would have preferred a two-stage implementation, first to abolish fees for childbirth for women and then, six months later, extend it to children under five. But the President of the Republic wanted these to be implemented at the same time and within one month after the declaration by the Council of Ministers. Thus, in April 2016 all the health districts of the Centre, Hauts-Bassins, and Sahel regions launched the national policy. Then in May 2016 it was applied in all regional and university hospitals. Finally, as of June 1, 2016, all other districts in the country organised exemptions from user fees.

Figure 1 provides a summary of the chronology of significant events and key stakeholders.

\section{Discussion}

In the following discussion, we generalise our findings to the conceptual and theoretical levels to compare our analysis with the most relevant literature in the fields of public policy science and knowledge transfer. We then offer some lessons learned for those wishing to engage in processes to influence decision-making using evidence. Finally, we present the methodological strengths and limitations of our analysis.

Conceptual and theoretical discussion: public policies and knowledge transfer. Even more than ideas and institutions (Béland, 2016), the role of power in political decisions is obvious, as has been shown by the case of Rwanda and its system of mutual insurance with compulsory membership (Chemouni, 2018). The preponderant role of presidents in the decisions to launch free healthcare policies in Africa (Ghana in 2008, Uganda in 2001, Zambia in 2005, etc.) has been widely demonstrated (Meessen et al., 2011; Ridde and Morestin, 2011). Indeed, recent work in Africa has shown that "the driving force for reform has been where social assistance is incorporated as an element of the political survival strategies employed by domestic political elites to build regime legitimacy, secure political allegiance, or win over electoral support" (Hickey et al., 2018). However, in the context of Burkina Faso, while the new President called for implementation to start quickly, the process was not rushed. Thus it took eight years for the national policy to be decided after the first pilot projects, which, in the field of public policy change, is not so long in the end (Sabatier and Weible, 2014). The changes were gradual, depending on the path dependency and, in particular, on the evolution of decision-makers' ideas, and confirmed that "continuity, at first glance, far outweighs any disruptions" (Lascoumes, 2006). The policy instruments (user fees) were modified over the years-being first reduced, then abolished for part of the population-shaped in particular by political manoeuvres, the ideas of influential actors, and the context of development aid institutions and their multiple projects (the role of the ECHO being central due to the scale of its funding). The production of scientific evidence by legitimate actors that could be mobilised by knowledge brokers, NGOs, and advocacy activists was also instrumental.
If we refer to Hall's (1993) proposals on public policy paradigms, we could argue we are seeing a third-order change, since the abolition of user fees and the evolution of the thinking around this led to the formulation of a new public policy of user fees exemption with an explicit view to achieving UHC. This paradigm shift was made possible in part through the mobilisation of advocacy coalitions (Sabatier and Weible, 2014) acting as political entrepreneurs (Ridde, 2009; Béland, 2016), as well as by the growing number of actors as the process progressed and the move beyond technical debates alone, as Hall (1993) suggested. Individual political entrepreneurs also influenced the process, as did, for example (among others!), the two authors of this article over 10 years: VR by his continued mobilisation of a large research team and PY by his constant involvement in the internal political process at the Ministry of Health, where his colleagues have now nicknamed him "Doctor Free Care". In-depth analysis will be needed to explore the role of "successful policy entrepreneurs" (Weible and Cairney, 2018) in the policy agenda setting. Our reflection leads us to believe international and national NGOs (with their specific expertise), as well as their donors (especially ECHO), have largely played this role of political entrepreneurs. Independent research will be needed to better understand this.

By 2018, the national strategy is in place, almost entirely financed by the State (98.54\%). The NGOs that launched the pilot projects in 2008 are now monitoring the effectiveness of the policy in 2018 with funding from the State itself. This separation of functions and the involvement of civil society in the governance and accountability process are two of the factors for successful implementation. Obviously, this current implementation of the policy faces many challenges (availability of drugs, delays in reimbursement, adjustment of amounts purchased, etc.) that will require analysis by subsequent research. Our aim in this article has been to focus solely on the history of decision-making, from our reflexive standpoint, and on the role of evidence in particular. Indeed, as the case of prison policies in South Africa shows, "a paradigm shift is not sufficient in itself. If it is not translated into a public policy programme and operationalised by a set of concrete measures and implemented, there is only a change of surface and the new paradigm dissolves into a smokescreen" (Lascoumes, 2006).

The considerable investments in not only generating knowledge but also mobilising it through knowledge brokering activities, storytelling techniques, and advocacy certainly contributed to this policy decision and the evolution of ideas (Dagenais et al., 2016; Cairney and Kwiatkowski, 2017; Dalglish et al., 2017; Davidson, 2017; Weible and Cairney, 2018). Moreover, these investments were made over a very long period, mobilising not only recognised international and national scientists, but also civil society actors, to put this work into action. The legitimacy of those who produced and presented the research results was certainly a positive factor in the consideration of the evidence. Patience, the accumulation of evidence, and the organisation of a broad coalition of actors were certainly success factors. We saw that sometimes obstacles were set up to prevent dissemination of the evidence in the media, and the NGOs had to accept that, for their advocacy to be effective, they needed to take into account the political issues.

Partnerships between researchers and NGOs can be advantageous (Olivier, Hunt and Ridde, 2016), and, as in Uganda and Ethiopia, the coordinated efforts of transnational actors is a success factor in influencing states (Hickey et al., 2018). During the process described here, research on knowledge transfer activities was even conducted to improve the strategy and make it more effective (Dagenais et al., 2013; D’Ostie-Racine et al., 2016). The science of using science (Langer et al., 2016) was therefore an 


\section{Box 1 | Lessons learned for evidence-informed decision-making in a low-income country context}

For states and donor decision-makers

-Fund and evaluate pilot projects to generate evidence on innovations while involving researchers in all stages

-Wait for the results of the pilot projects before moving to a larger scale

-Systematically include in intervention budgets funding for evaluations and knowledge transfer activities

-Recruit, train, and mobilise individuals and/or services responsible for knowledge transfer activities

-Take into account the source of the production of scientific evidence in a context where there is a strong presence of multiple international donors

For researchers

-Identify and partner with political entrepreneurs early and regularly

-Persevere and be consistent in producing rigorous and useful evidence

-Take context into account when generating evidence (who funds what, for what purposes and expected uses, etc.)

-Favour independent teams for intervention evaluations, and promote the use of mixed methods

- Value the external validity of research results in the same way as internal validity

-Disseminate research results regularly and in a format appropriate to the target audience

-Anticipate the knowledge needs of decision-makers and formulate research that attempts to address them

For knowledge brokers

-Be well trained in knowledge transfer processes and tools

-Train decision-makers and researchers in knowledge transfer

-Train researchers in policy decision-making processes and decision-makers in knowledge production issues

-Adapt (content, format, vocabulary, language, etc.) evidence in close collaboration with researchers and disseminate it to different target audiences

- Understand the different logics of researchers and decision-makers and act as an intermediary between these two worlds to promote their interaction

-Analyse policy decision-making processes specific to the national context, as well as the social and political contexts favourable (or not) to decision-

making, to be able to seize opportunities

-Understand the context within which the media operate

-Partner with civil society organisations specialised in the field (health, education, transport, etc.)

For civil society actors

-Pool efforts in the form of a consortium to boost advocacy actions

-Work closely with researchers to build evidence to facilitate advocacy actions

-Identify and collaborate with key actors, decision-makers, and government workers who are able to engage in evidence-based advocacy to change people's minds and ways of working

-Be patient and persevering in advocating for social and behavioural change to improve population health

undeniable help, and "finally, it is important to acknowledge the central role that numbers and scientific reasoning play in many public problems" (Neveu, 2017). It was also essential to work with open-minded researchers (and others who became openminded), ready to invest themselves in this long-term adventure, agreeing to publish results first to national decision-makers (in French and using lay vocabulary; see, for instance, the Nigerien case (Dalglish et al., 2017)) before disseminating them in renowned international scientific journals-strategies for which academic institutions are not yet very well prepared.

The change in policy paradigm cannot be explained solely by practical developments in policy instruments, but also, as suggested by Hall (1993), "social learning as a causal mechanism suggests that paradigm change comes about through evidencebased deliberation of policy success or failure ('learning' or 'puzzling'), supplemented by external struggle for institutional resources ('powering')" (Wood, 2015). Thus, the evolution of ideas regarding political instruments was certainly as essential a factor of influence (Béland, 2016), as was the evolution of power and interests (Béland, 2010); this was clearly shown with regard to the UHC policy in Rwanda, where historical analysis showed that "besides power, ideas mattered" (Chemouni, 2018). With regard to the user fees exemption, the abundance of locally generated evidence certainly had an impact in countering preconceived ideas (Ridde et al., 2014). Thus, the use of research results in this context was not only instrumental in facilitating decision-making but certainly also conceptual in changing ideas (Weiss, 1979). In particular, it required "the work of enticing journalists" (Neveu, 2017) and policy-makers to "consider 'cognitive biases' from the perspective of policymakers instead of bemoaning them from our own" (Cairney and Kwiatkowski, 2017). Unlike in Rwanda, where officials' ideas on user fees have remained static and have focused on another type of policy for UHC (Chemouni, 2018), the ideas of decision-makers in Burkina Faso have evolved towards accepting the user fees abolition.

Moreover, we should not minimise the essential role of the late 2014 uprising, the famous 'window of opportunity' (a concept brought to light by Kingdon (1995)), among other factors, in explaining the emergence of public policies. The challenge now is to better understand the role of this type of event in a Burkinabè society characterised at that time as semi-authoritarian (Hilgers and Mazzocchetti, 2010), given that Kingdon's (1995) concept and approach were developed in the United States of America, a liberal democracy, in the 1980s.

Lessons learned. Following on the results of our reflection in the preceding pages and their relationship with the scientific literature on public policy and knowledge transfer, in this section we propose some lessons learned. Box 1 offers practical suggestions for the four main types of actors (decision-makers, researchers, knowledge brokers, civil society) concerned by the desire to consider evidence more effectively in political decision-making. Obviously, it is essential to take into account the social, political, and economic contexts and the nature of the evidence (Craig et al., 2018; Weible and Cairney, 2018), but our focus here is on lessons learned for these four main stakeholder groups. These 
lessons were formulated based on the evidence presented above and were the subject of a consensus discussion between the two authors supported by a colleague expert in the field (C. Dagenais). Their formulation is relatively generic to allow their adaptation to the specific context of the reader working in a low-income country, because obviously we are not proposing miracle solutions or best practices, but rather "high-quality lesson[s] learned" (Patton, 2001).

On 27 September 2017, the Government approved a reorganisation of the Ministry of Health proposed by the new minister. This made it possible to create a strategic unit directly attached to the minister's office, the Knowledge Management and Transfer Unit (KTMU). The aim of this unit within the Ministry is to better integrate research data into both decision-making and health system management at all levels. KTMU's mission is to inform evidence-based public health decision-making and to enhance the intellectual capital of the health sector. The lessons we discuss in this article will certainly be useful for the development of this unit, which remains an innovation in West Africa to date.

Methodological considerations. At the methodological level, the strengths of our article are, first, the fact that the reflections were carried out by two actors extensively involved in the process and with detailed knowledge of it; and, second, the use of a simple descriptive framework to present the results, associated in the Discussion with other analytical frameworks that might increase their potential generalisability. Moreover, for an article to be written by a researcher and a decision-maker together is both rare and instructive for public policy analysis. Weaknesses are related to the depth of analysis, which could be enhanced by the collection of specific empirical data, and the authors' involvement in the process, such that independent analysis would be useful to improve or confirm the conclusions. Moreover, our reference in the Discussion section to certain analytical frameworks (e.g., Sabatier, Kingdon, and Hall) remains limited and is offered heuristically, to integrate our reflection into a more global public policy analysis field. Their use with original empirical data and the application of all their analytical dimensions would be indispensable in a future study.

\section{Conclusion}

Ten years ago, we showed how the lack of consideration for equity in health policies in Burkina Faso was partly explained by the absence of political entrepreneurs mobilised to seize windows of opportunity (Ridde, 2008). History does not seem to have repeated itself. Nevertheless, the process has taken a relatively long time and has required a very substantial body of evidence generated from interventions reliably funded by donors motivated for change, the implementation of multiple knowledge transfers strategies, the efforts of collective and individual political entrepreneurs, effective and patient advocacy coalitions, aided by a major window of opportunity that they seized and used to good effect. The role of evidence in the decision-making around this national policy of user fees exemption of healthcare in Burkina Faso was therefore essential, but certainly no more nor less than were all these other factors whose individual contributions are certainly impossible to evaluate. Indeed, "Any policy actor-as well as policy scholars-should not be too self-critical of their lack of influence. The policy process is too complex to guarantee impact" (Weible and Cairney, 2018).

Received: 9 April 2018 Accepted: 12 September 2018 Published online: 02 October 2018

\section{Notes}

1 https://ouagadougou2013.sciencesconf.org

2 From http://www.equiperenard.ca

\section{References}

Amnesty International (2009) Giving life, risking death. Maternal mortality in Burkina Faso. Amnesty International Publications, London, p 112

Amnesty International (2010) President of Burkina Faso commits to lifting financial barriers to maternal health in a meeting with Amnesty International. Amnesty International, London

Baptist C, Miletzki J (2017) Working towards universal health coverage in Burkina Faso. GSK and Save The Children, London, p 10

Béland D (2010) The idea of power and the role of ideas. Political Stud Rev 8 (2):145-154. https://doi.org/10.1111/j.1478-9302.2009.00199.x

Béland D (2016) Kingdon reconsidered: ideas, interests and institutions in comparative policy analysis. J Comp Policy Anal 18(3):228-242

Blanchet K, Zonon NA, Aggagliate T (2012) La gratuité des soins est rentable: la preuve par un projet pilote au Burkina Faso. Revue Humanitaire, 31(mis en ligne le 11 mai 2012, Consulté le 25 juillet 2012

Cairney P, Kwiatkowski R (2017) How to communicate effectively with policymakers: combine insights from psychology and policy studies. Pal Commun 3 (1). https://doi.org/10.1057/s41599-017-0046-8

Chemouni B (2018) 'The political path to universal health coverage: power, ideas and community-based health insurance in Rwanda'. World Dev 106:87-98. https://doi.org/10.1016/j.worlddev.2018.01.023

Cotlear D, Rosemberg N (2018) Going Universal in Africa: How 46 African Countries Reformed User Fees and Implemented Health Care Priorities. World Bank Group, Washington, DC., p 38

Craig P et al. (2018) Taking account of context in population health intervention research: guidance for producers, users and funders of research. https://doi. org/10.3310/CIHR-NIHR-01

Dagenais C et al. (2016) A Knowledge Brokering Program in Burkina Faso (West Africa): reflections from our experience. Health Syst Reform 2(4):367-372. https://doi.org/10.1080/23288604.2016.1202368

Dagenais C, Queuille L, Ridde V (2013) Evaluation of a knowledge transfer strategy from user fee exemption program for vulnerable populations in Burkina Faso, Special Issue on Vulnerability and Health in Africa. Global Health Promotion 20(1 Suppl):70-79

Dagenais C, Ridde V (2018) Policy brief (PB) as a knowledge transfer tool: To "make a splash", your PB must first be read Gaceta Sanitaria, Gac Sanit 2018;32:203-5 - Vol. 32 Núm.3, https://doi.org/10.1016/j.gaceta.2018.02.003

Dalglish SL et al. (2017) Knowledge and power in policy-making for child survival in Niger. Soc Sci Med 177:150-157. https://doi.org/10.1016/j. socscimed.2017.01.056

Davidson B (2017) Storytelling and evidence-based policy: lessons from the grey literature. Pal Commun 3:17093. https://doi.org/10.1057/palcomms.2017.93

DG ECHO (2007) Humanitarian aid for vulnerable populations at risk in the Sahel Region of WestAfrica. Global plan 2007. Humanitarian Aid Committee. European Commission, Brussels. Directorate General for Humanitarian Aid$\mathrm{ECHO}, \mathrm{p} 25$

DG ECHO (2008) DG ECHO position paper on user fees for primary health services in humanitarian crises. European Commission, Bruxelles, Directorate General for Humanitarian Aid-ECHO

D'Ostie-Racine L, Dagenais C, Ridde V (2016) A qualitative case study of evaluation use in the context of a collaborative program evaluation strategy in Burkina Faso. Health Res Policy Syst 14(1):37. https://doi.org/10.1186/ s12961-016-0109-0

Gautier L, Ridde V (2017) Health financing policies in Sub-Saharan Africa: government ownership or donors' influence? A scoping review of policymaking processes. Glob Health Res Policy 2:23

Hall P (1993) Policy paradigms, social learning and the state: the case of economic Policymaking in Britain. Comp Polit 25(3):275-296

Hassenteufel P (2010) Les processus de mise sur agenda: sélection et construction des problèmes publics. Inf Soc 157(1):50-58

HERA (2018) Evaluation In Itinera de l'Initiative Solidaté Santé Sahel (I3S). Rapport final provisoire. HERA, Bruxelles, Belgique

Hickey S et al. (2018) The Negotiated Politics Of Social Protection In Sub-Saharan Africa. Helsinki: WIDER Working Paper 2018/34: UNU-WIDER, p 32

Hilgers M, Mazzocchetti J (eds) (2010) Révoltes et oppositions dans un régime semi-autoritaire. Le cas du Burkina Faso.

Howlett MP (2011) Designing public policies: principles and instruments. Routledge, London; New York, (Routledge textbooks in policy studies)

Johri $\mathrm{M}$ et al. (2014) Estimation of maternal and child mortality one year after user-fee elimination: an impact evaluation and modelling study in Burkina Faso. Bull World Health Organ 92(10):706-715. https://doi.org/10.2471/ BLT.13.130609

Kingdon JW (1995) Agendas, alternatives and publics policies, 2nd edn. Harper Collins, New York 
Langer L et al. (2016) The science of using science: researching the use of research evidence in decision-making. University of London, Social Science Research Unit, at Evidence for Policy and Practice Information and Co-ordinating Centre

Lascoumes P (2006) Ruptures politiques et politiques pénitentiaires, analyse comparative des dynamiques de changement institutionnel. Déviance Et Société 30(3):405. https://doi.org/10.3917/ds.303.0405

Meessen B et al. (2011) 'Removing user fees in the health sector: a review of policy processes in six sub-Saharan African countries'. Health Policy Plan 26(Suppl. 2):ii16-ii29

Ministère de la Santé (2012) Étude de faisabilité de l'exemption du paiement direct des soins curatifs chez les enfants de moins de 5 ans au Burkina Faso. Ministere de la Santé, Ouagadogou

Ministère de la santé (2017) Comptes de la santé 2016. Comptes globaux \& Dépenses de santé du Paludisme, du VIH/Sida, de la Tuberculose et de la Santé de la Reproduction. Ministère de la santé, Ouagadougou, p 40

MSF (2017) Taxing the ill: how user fees are blocking Universal Health Coverage. MSF, brussels, $p 17$

Neveu E (2017) L'analyse des problèmes publics: un champ d'étude interdisciplinaire au cœur des enjeux sociaux présents. Idées économiques Et Soc 190(4):6. https://doi.org/10.3917/idee.190.0006

Nguyen TH et al. (2018) The impact of reducing and eliminating user fees on facility-based delivery: a controlled interrupted time-series in Burkina Faso. Health Policy Planning. https://doi.org/10.1093/heapol/czy077

Olivier C, Hunt MR, Ridde V (2016) NGO-researcher partnerships in global health research: benefits, challenges, and approaches that promote success. Dev Pract 26(4):444-455. https://doi.org/10.1080/09614524.2016.1164122

Olivier de Sardan J-P, Ridde V (2015) Public policies and health systems in Sahelian Africa: theoretical context and empirical specificity. BMC Health Serv Res 15(Suppl 3):S3. https://doi.org/10.1186/1472-6963-15-S3-S3

Patton MQ (2001) Evaluation, knowledge management, best practices, and high quality lessons learned. Am J Eval 22(3):329-336

Pawson R (2013) The science of evaluation: a realist manifesto. Sage Publications, Thousans Oaks, p 216

Queuille L et al (2013) Capitalisation de Knowledge Mobilization pour améliorer l'accès aux soins des populations vulnérables du Sahel-Burkina Faso. 81ème congrès de l'ACFAS, Québec (Canada), 7 mai 2013, Québec (Québec)

Ridde V (2008) The problem of the worst-off is dealt with after all other issues: the equity and health policy implementation gap in Burkina Faso'. Soc Sci Med 66:1368-1378

Ridde V (2009) Policy implementation in an African State: an extension of the Kingdon's multiple-streams approach. Public Adm 87(4):938-954

Ridde $\mathrm{V}$ et al. (2011) The national subsidy for deliveries and emergency obstetric care in Burkina Faso. Health Policy Plan Supplement 2(26):ii30-ii40

Ridde V, Queuille L et al. (2012) Transversal analysis of public policies on user fees exemptions in six West African countries. BMC Health Serv Res 12:409. https://doi.org/10.1186/1472-6963-12-409

Ridde V, Zerbo R et al. (2012) Two Solitudes: Learning about Research Systems and Health Systems in Burkina Faso through the History of User Fees (April)

Ridde $\mathrm{V}$ et al. (2014) Les modalités de collecte du financement de la santé au Burkina Faso de 1980 à 2012. St Publique (Vandoeuvre-Lès-Nancy, Fr) 26 (5):715-725

Ridde V (2015) From institutionalization of user fees to their abolition in West Africa: a story of pilot projects and public policies. BMC Health Serv Res 15 (3):1-11. https://doi.org/10.1186/1472-6963-15-S3-S6

Ridde V et al. (2015) The impact of user fee removal policies on household out-ofpocket spending: evidence against the inverse equity hypothesis from a population based study in Burkina Faso. Eur J Health Econ 16(1):55-64. https://doi.org/10.1007/s10198-013-0553-5

Ridde V, Morestin F (2011) A scoping review of the literature on the abolition of user fees in health care services in Africa. Health Policy Plan 26(1):1-11

Ridde V, Queuille L (2010) User fees exemption: one step on the path toward universal access to healthcare. CRCHUM/HELP/ECHO, Ouagadougou, $\mathrm{p} 44$

Ridde V, Queuille L, Ndour M (2014) Nine misconceptions about free healthcare in sub-Saharan Africa. Dev Stud Res 1(1):54-63. https://doi.org/10.1080/ 21665095.2014.925785

Robert E et al. (2017) Building a middle-range theory of free public healthcare seeking in sub-Saharan Africa: a realist review. Health Policy Plan 32 (7):1002-1014. https://doi.org/10.1093/heapol/czx035
Robert E, Ridde V (2013) Global health actors no longer in favor of user fees: a documentary study, Globalization Health 9(29) https://doi.org/10.1186/17448603-9-29

Sabatier PA, Weible CM (eds) (2014) Theories of the policy process, 3rd edn. Westview Press, Boulder, CO, a member of the Persus Books Group

Samb OM, Ridde V (2018) The impact of free healthcare on women's capability: a qualitative study in rural Burkina Faso. Soc Sci Med 197:9-16. https://doi.org/ 10.1016/j.socscimed.2017.11.045

Tremblay M-C, Parent A-A (2014) Reflexivity in PHIR: let's have a reflexive talk!. Can J Public Health 105(3):e221-e223. https://doi.org/10.17269/ cjph. 105.4438

Weible CM, Cairney P (2018) Practical lessons from policy theories. Policy Polit 46 (2):183-197. https://doi.org/10.1332/030557318X15230059147191

Weiss C (1979) The many meanings of research utilization. Public Adm Rev 39 (5):426-431

WHO and World Bank (2017) Tracking Universal Health Coverage: 2017 Global Monitoring Report. World Health Organization and International Bank for Reconstruction and Development/The World Bank, p 70

Wood M (2015) Puzzling and powering in policy paradigm shifts: politicization, depoliticization and social learning. Crit Policy Stud 9(1):2-21. https://doi. org/10.1080/19460171.2014.926825

Yates R, Brookes T, Whitaker E (2017) Hospital detentions for non-payment of fees: a denial of rights and dignity. Chatham House, London, $\mathrm{p} 17$

\section{Data availability}

Data sharing is not applicable to this article as no datasets were generated or analysed during the current study.

\section{Acknowledgements}

Our thanks to the participants at the conference of the Critical Investigations into Humanitarianism in Africa (CIHA) Blog (Senegal, Dec 2017) for their questions, which helped improve our reflections presented in this article. We would like to warmly thank Serge Alfred Sedogo, Amandine Fillol, Daniel Béland, Christian Dagenais, and Adama Hema for their comments on an earlier version. The authors would also like to thank Donna Riley for her editing support. Lastly, thanks also go to the late Gaëtan Mootoo, a researcher at Amnesty International, who played a part in the work described.

\section{Additional information}

Competing interests: The two authors have served as consultants to non-governmental organisations on the issue of user-fees abolition. The funders and NGOs had no role in this study or the decision to submit the article for publication.

Reprints and permission information is available online at http://www.nature.com/ reprints

Publisher's note: Springer Nature remains neutral with regard to jurisdictional claims in published maps and institutional affiliations.

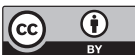

Open Access This article is licensed under a Creative Commons Attribution 4.0 International License, which permits use, sharing, adaptation, distribution and reproduction in any medium or format, as long as you give appropriate credit to the original author(s) and the source, provide a link to the Creative Commons license, and indicate if changes were made. The images or other third party material in this article are included in the article's Creative Commons license, unles indicated otherwise in a credit line to the material. If material is not included in the article's Creative Commons license and your intended use is not permitted by statutory regulation or exceeds the permitted use, you will need to obtain permission directly from the copyright holder. To view a copy of this license, visit http://creativecommons.org/ licenses/by/4.0/

(c) The Author(s) 2018 